\title{
Clinical Management of Marasmus Protocol (Case Study)
}

\author{
Shadia Mohamed ${ }^{1}$, Ali Adam Juma², Bashir Awil Ismail ${ }^{3}$ \\ ${ }^{1,2,3}$ Univerity of Bahri, College of Public Health and Environmental Health
}

\begin{abstract}
According to the world health organization 49\% of the 10.4 million deaths occurring in children younger than 5 years in developing countries are associated with PEM. The purpose of this study to identify the clinical management of the children affected with marasmus and understands of protocol treatment. Methods and Material: This study targeting health professionals at the hospitals and under five year marasmic children treatment processes. Fifty (50) samples were interview from whole professionals with different health specialists in malnourished children wards at Khartoum-Bahri Teaching Hospital and Ahmed Qassem hospital-Sudan working staffs. The tool used in the study was questionnaire. Result: (76\%) of the respondent confirm the major factors that causes marasmus were parents awareness and lack of balance diet. (90\%) of the respondent agree the national and international treatment protocols have been applying at the hospitals. (90\%) were sure that undergo enough treatment and flow up for marasmic child at the hospitals. (56\%) agree about the number of children with marasmus that attended to the hospitals in the past five years increases year after year. $66 \%$ were revealed that suitable treatment for children with marasmus are balance diet, vitamins supplementation and ORS (oral dehydration solutions) Conclusion: Both hospitals have been use national and international treatment protocols. All health professionals have being working continuously while affected children come to hospitals increase year after year.
\end{abstract}

Keywords: Marasmus, Child health, Balance diet, Protocol, Sudan

\section{Introduction}

Maramus is a form of severe malnutrition characterized by energy deficiency. A child with marasmus looks emaciated. Body weight is reduced to less than $60 \%$ of the normal (expected) body weight for the age. (1)

\subsection{History of Marasmus}

The protein-calorie malnutrition in infancy must have been common in most of the world for centuries, but attention has only been focused upon it within the last $50^{\text {th }}$ years.

Marasmus was not uncommon in the industrial towns of Europe and North

Protein Calorie Malnutrition is the most common type of nutritional deficiency in hospitalized patients and is manifested by depletion of tissue, energy stores and body protein.

Malnourished patient have prolonged hospitalization and are at a higher risk of developing complication during therapy. These nutrition-associated complications are the result of organ wasting and functional impairment and include weakness decreased wound healing hepatic metabolism of drugs, and infections. (2)

Diets and deficiencies may vary considerably between different geographical regions and even within a country. Marasmus is typically observed in infants who are breastfeeding when the amount of milk is markedly reduced or more frequently, in those who are artificially fed. (3)

\subsection{Factors and Causes of Marasmus}

Good food in adequate quantities is important for the preservation of health. Whenever there is shortage of the former the individual might suffer from variable degrees of malnutrition, which is usually well manifested in infancy and childhood.

Also poverty, ignorance, drought, war, earthquakes, and floods were suffered from; either collectively or in party in most civilization of the world at one time or the other. These factors usually associated with food shortage and starvation.

Immediate and underlying causes are engaged in the occurrence of malnutrition. Immediate causes include inadequate dietary intake and illness, while the underlying causes include: inadequate excess to food in the household, insufficient health services and healthy-full-environment". Famines, wars and other catastrophes are responsible for only tiny part of the world wide malnutrition crises, but such emergencies often result in the severest forms of malnutrition. (4) (5)

\subsection{Global Situation}

The latest prevalence estimates of stunting and underweight among children under-five years of age worldwide suggest that there have been decreases since 1990. While progress has been made, it is insufficient-leaving millions of children at risk of lower chances for survival.

The current trends continue United Nations (UN) regional projections for 2015 indicate that the goal of halving the 1990 underweight prevalence levels is unlikely to be achieved on a global level or in all developing countries.

Estimates from 2011 suggest stunting prevalence reductions of more than $40 \%$ in Asia and Latin America and the Caribbean since 1990. Reductions in Africa and Oceania have been more modest (10-15\%). During the same period, reductions in the prevalence of underweight were $56 \%$ in Latin America and the Caribbean. (6) 


\section{International Journal of Science and Research (IJSR) \\ ISSN (Online): 2319-7064}

Index Copernicus Value (2013): 6.14 | Impact Factor (2014): 5.611

Childhood under-nutrition is an underlying cause of 35 percent of deaths among children under five years old in the developing world. According to the 2008 Lancet Series on Maternal and Child Under-nutrition, Severe Acute Malnutrition (SAM) is one of the most important contributing causes of childhood mortality. An estimated 19 million children under five suffer from SAM, with half a million dying directly because of SAM each year. These numbers do not include children suffering from bilateral pitting edema, which is the most lethal form of acute malnutrition (7).

Sudan has persistent elevated levels of under-nutrition. Poor health conditions, suboptimal maternal and child feeding and care practices, and food insecurity, compounded by high rates of poverty and illiteracy, play a complex and interrelated role as contributing factors to the widespread under nutrition. Although rates vary significantly between states, nationally the global acute malnutrition (GAM) is 14.8 percent $(<-2$ WFH z-score), just below internationally recognized thresholds for a nutrition emergency. (8).

Underscoring pervasive, long-term under nutrition and morbidity throughout the country, other nutrition indicators are also poor: 31 percent of children under age five are underweight $(<-2$ WFA $\mathrm{z}$-score) and 32.5 percent are stunted $(<-2$ HFA z-score). While data are limited, available information from localized surveys suggests that micronutrient deficiencies are also prevalent. According to the majority of nutrition surveys, the greatest risk of under nutrition is among children 6-29 months, indicating that sustained efforts to address the nutrition needs in this age group are critical. (9)(10)

Tens of children under the age of five remain at risk of marasmus and malnutrition-related death in Sudan, despite temporary improvements in the food security situation that were released today by the Integrated Food Security Phase Classification (IPC) group of experts. (11)

Slow recovery among survivors has been shown to be associated with insufficient provision of energy and nutrients necessary for rapid catch-up growth. Centers that have changed their treatment practices, however, have drastically reduced their case fatality rates. (12).

Brazil, implementation of the World Health Organization (WHO) guidelines for management of severe malnutrition substantially increased rates of recovery. These experiences suggest that evaluation of clinical practice is important. (13)

\subsection{Treatment of Marasmus}

Although there is no huge measurable difference between all malnutrition diseases as hospitals treatment uses that only depend on the severity level of the affected children. Marasmus is usually treated by adding vitamin B and following a nutritious diet in general. (14).

Treatment is designed to provide adequate nutrition, restore normal body composition, and cure the condition that caused the deficiency. Tube feeding or intravenous feeding is used to supply nutrients to patients who cannot or will not eat protein-rich foods. (15)

\subsection{Clinical Management}

The clinical management of severely malnourished children can be rapidly assessed to highlight areas for improvement. Involving staff in the assessment process has led to their active involvement in improving the management of malnourished children in their hospitals. (16)

A review of treatment practices worldwide found that many health services use discredited practices and that staffs are unfamiliar with modem, effective guidelines for the management of severe malnutrition.' Inappropriate practices associated with high mortality include overuse of intravenous (IV) fluids for rehydration, inadequate feeding leading to hypoglycemia and hypothermia, untreated infections, and failure to correct electrolyte and micronutrient deficiencies.

(WHO) guidelines for management of severe malnutrition substantially increased rates of recovery.' These experiences suggest that evaluation of clinical practice is important. (16)

\subsection{Role of Health Team Professionals}

The health care team comprises all the health care professionals that work with a given patient or patients and their families toward the common goal of patient health. These include medical part of team (physician, nurse, dietitian, physical therapist, and pharmacist).

a) The physician: generally the person with most broadbased knowledge related to patient health care is the medical doctor (MD), otherwise refer to as the physician. The physician knows the patient medical history and has general understanding of the relationship between diseases states and other health concerns.

b) The nurse: the nurse generally has the most contact with the individual patients and their families the nurse can provide other members the health care team. With good insight into patient needs because of this in depth patients contact. Ongoing assessment and monitoring of patient eating habits and health status are important roles of the nurse.

c) The physical therapist: assisting in promoting mobility and physical movement to control pain is part of the role of the physical therapist (PT). a physical therapist may be involved with helping a person enhance capabilities that have been impaired due to illness or trauma. The PT may promote exercise that is appropriate for individual to promote weigh loss on increase muscle strength.

d) The pathologist: the professional to consult when assessing the seemingly simple act of swallowing is the speech the pathologist. Swallowing series of interrelated steps can be seriously impaired due to stroke or other neurological damage.

e) The pharmacist: the registered pharmacist is responsible for preparing the nutritional solutions that the physician orders these solutions are administered through veins or enteral routes. 


\section{International Journal of Science and Research (IJSR) \\ ISSN (Online): 2319-7064 \\ Index Copernicus Value (2013): 6.14 | Impact Factor (2014): 5.611}

f) The registered dietitian: the registered dietitian or $\mathrm{RD}$ is the health care professional best qualified to interpret the science of how foods is used by the body in health and disease states and to evaluate how changes in the diet can improve the patient health status.

g) The nutritionist: a nutritionist is educator, as well as a counselor, who usually works in a public health setting and who typically has a at least a bachelor's degree in nutrition. The legal credential certified or licensed nutritionist is used in some states to help indicate qualified nutritionists. (17) (18).

\section{Result and Discussion}

Table 1: Gender Characteristics

\begin{tabular}{|l|c|c|}
\hline \multicolumn{1}{|c|}{ Characteristics } & Frequency & $\%$ \\
\hline Gender & & \\
Male & 10 & $20 \%$ \\
Female & $\underline{40}$ & $80 \%$ \\
Total & 50 & $100 \%$ \\
\hline$\underline{\text { Age }}$ & & \\
$18-25$ & 19 & $38 \%$ \\
$26-45$ & 28 & $56 \%$ \\
$46-65$ & $\underline{3}$ & $6 \%$ \\
Total & 50 & $100 \%$ \\
\hline Occupation & 24 & 48 \\
Doctor & 7 & 14 \\
Nutritionist & 19 & 38 \\
Nurse & $\underline{0}$ & 0 \\
Other & 50 & $100 \%$ \\
Total & \multicolumn{2}{|c}{} \\
\hline \multicolumn{2}{|c|}{}
\end{tabular}

Table 1 shows gender characteristic. $80 \%$ were female. $56 \%$ of the age characteristics are 25-45 years. Occupational analyses show that $48 \%$ are doctors. This due to in the hospitals the doctors workers are more than other health professional workers.

Table 2: Factors that causes marasmus

\begin{tabular}{|l|l|l|}
\hline Respond & Frequency & Percent \\
\hline Parents awareness & 15 & $30 \%$ \\
\hline Economic & 9 & $18 \%$ \\
\hline Culture & 1 & $2 \%$ \\
\hline $\begin{array}{l}\text { Awareness } \\
+ \text { economic } \\
+ \text { culture }\end{array}$ & 25 & $50 \%$ \\
\hline Total & 50 & $100 \%$ \\
\hline
\end{tabular}

Table (2) shows major factors that causes marasmus. The study revealed that parent awareness with balance diet, economic and cultural factors represent $50 \%$ as causes of marasmus.

Table 3: Degree of Marasmus in the hospital

\begin{tabular}{|c|c|c|}
\hline Respond & Frequency & $\%$ \\
\hline low & 4 & $8 \%$ \\
\hline Median & 27 & $54 \%$ \\
\hline Sever & 19 & $38 \%$ \\
\hline Total & 50 & $100 \%$ \\
\hline
\end{tabular}

Table (3) shows that process of severe mal-nutrition treatment in hospitals, median degree represents 54\%.
Table 4: Apply of National and International protocol

\begin{tabular}{|c|c|c|}
\hline Respond & Frequency & $\%$ \\
\hline Agree & 45 & $90 \%$ \\
\hline Disagree & 5 & $10 \%$ \\
\hline Total & 50 & $100 \%$ \\
\hline
\end{tabular}

Table 4 shows the international treatment protocols to child with marasmus, apply in both hospitals. $90 \%$ of respondent professionals agreed that international treatment protocols applied.

Table 5: Enough Treatment and Flow up

\begin{tabular}{|c|c|c|}
\hline Respond & Frequency & $\%$ \\
\hline Agree & 45 & $90 \%$ \\
\hline Disagree & 5 & $10 \%$ \\
\hline Total & 50 & $100 \%$ \\
\hline
\end{tabular}

Table 5. Represent the opinion of the respondent about the enough treatment and flow up in hospitals for the marasmic child. $70 \%$ of the respondents agreed that treatment and flow up are enough in the hospital. This means in the hospitals treatment and flow up are high.

Table 6: Signs and symptoms are appear at first visit to the hospital

\begin{tabular}{|c|c|c|}
\hline Respond & Frequency & $\%$ \\
\hline Agree & 38 & $76 \%$ \\
\hline Strong agree & 10 & $20 \%$ \\
\hline Disagree & 2 & $4 \%$ \\
\hline Strong Disagree & 0 & $0 \%$ \\
\hline Total & 50 & $100 \%$ \\
\hline
\end{tabular}

Table 6. Shows the clinical feature module of signs and symptoms are clear identified at the first visit to the hospital. $76 \%$ of the respondents are agreeing. The study revealed that the clinical feature module of signs and symptoms with marasmus malnourished child is clear on the first visit.

Table 7: Marasmus caused by fewer food intake of the child

\begin{tabular}{|c|c|c|}
\hline Respond & Frequency & $\%$ \\
\hline Agree & 26 & $52 \%$ \\
\hline Strong agree & 20 & $40 \%$ \\
\hline Disagree & 3 & $6 \%$ \\
\hline Strong disagree & 1 & $2 \%$ \\
\hline Total & 50 & $100 \%$ \\
\hline
\end{tabular}

Table 7. Shows the opinion of the respondents about the fewer intakes is main cause of marasmus. Only $52 \%$ of the health professionals agreed that marasmus caused by fewer intakes of food than their needs.

Table 8: Children assessment at the hospitals

\begin{tabular}{|c|c|c|}
\hline Respond & Frequency & $\mathbf{\%}$ \\
\hline Under weight & 49 & $98 \%$ \\
\hline Above weight & 1 & $2 \%$ \\
\hline Normal weight & 0 & $0 \%$ \\
\hline Total & 50 & $100 \%$ \\
\hline
\end{tabular}




\section{International Journal of Science and Research (IJSR) \\ ISSN (Online): 2319-7064 \\ Index Copernicus Value (2013): 6.14 | Impact Factor (2014): 5.611}

Table 8. Shows the assessment of children with marasmus at admitted to the hospitals. Always $98 \%$ of the children admitted to the hospitals are under weight.

Table 9: Poverty affects the children with marasmus

\begin{tabular}{|c|c|c|}
\hline Respond & Frequency & $\%$ \\
\hline Greatly & 47 & $94 \%$ \\
\hline Slightly & 1 & $2 \%$ \\
\hline Moderately & 2 & $4 \%$ \\
\hline Not at all & 0 & $0 \%$ \\
\hline Total & 50 & $100 \%$ \\
\hline
\end{tabular}

Table 9. Represent the opinion of the respondents about the affects of poverty on the children with marasmus. $94 \%$ of the health professional at the hospitals are agree that main reason and affect on health of the child with marasmus is poverty.

Table 10: Marasmic children that came to the hospital in the past five years

\begin{tabular}{|c|c|c|}
\hline Respond & Frequency & $\%$ \\
\hline Increase yearly & 28 & $56 \%$ \\
\hline Decrease yearly & 10 & $20 \%$ \\
\hline Moderate increase & 11 & $22 \%$ \\
\hline Randomly & 1 & $2 \%$ \\
\hline Total & 50 & $100 \%$ \\
\hline
\end{tabular}

Table 10. Shows the number of children with marasmus admits to the hospital. $56 \%$ of the professionals agree that the number of children with marasmus admit to hospital in the past five years increase year after year.

Table 11: Problems faced the health professionals in the

\begin{tabular}{|c|c|c|}
\multicolumn{3}{|c}{ hospital } \\
\hline Respond & Frequency & $\%$ \\
\hline mother & 9 & $18 \%$ \\
\hline father & 2 & $4 \%$ \\
\hline Both of them & 34 & $68 \%$ \\
\hline None of them & 5 & $10 \%$ \\
\hline Total & 50 & $100 \%$ \\
\hline
\end{tabular}

Table 11. Explains, problems faced the health professionals in hospitals. $68 \%$ the professionals said that problems faced in clinical management mainly from parents.

Table 12: Suitable treatment for the children's with marasmus in hospital

\begin{tabular}{|c|c|c|}
\hline Respond & Frequency & $\%$ \\
\hline Balance diet and liquid & 17 & $34 \%$ \\
\hline Balance diet, liquid+ Drug & 33 & $66 \%$ \\
\hline Drug only & 0 & $0 \%$ \\
\hline ORS (oral dehydration solutions) & 0 & $0 \%$ \\
\hline Total & 50 & $100 \%$ \\
\hline
\end{tabular}

Table 12. Shows suitable treatment for the children's with marasmus at the hospitals.
The suitable treatment that uses in hospitals are Balance diet, liquid supply, tablets and ORS (oral dehydration solutions) those represents $66 \%$.

Table 13: Health professional recommendations to the parents.

\begin{tabular}{|l|l|l|l|}
\hline \multicolumn{2}{|c|}{ Recommendation for treatment } & Frequency & \\
\hline \multirow{3}{*}{ Healthy food } & 20 & $40 \%$ \\
\cline { 2 - 4 } Hygiene & 1 & $2 \%$ \\
\hline Children care & 12 & $24 \%$ \\
\hline Periodic diagnose & 1 & $2 \%$ \\
\hline Health awareness & 9 & $18 \%$ \\
\hline Breastfeeding & 2 & $4 \%$ \\
\hline other & 5 & $10 \%$ \\
\hline Total & 50 & $100 \%$ \\
\hline
\end{tabular}

Table No. 13. Show the health professional recommendation to the parent. $40 \%$ advised Healthy food as best way to avoid marasmus. The second advice to the parent $24 \%$ is child care.

\section{Conclusions}

Both hospitals have been use national and internationa treatment protocols, although the processes of marasmus treatment in hospitals are good. All health professionals have being working continuously while affected children come in hospitals increase year after year.

\section{Recommendations}

1) Increase parent's awareness about balance and healthy food.

2) Researches to study the causes for increase the number of children admitted to the hospitals.

\section{References}

[1] wikipediafoundation.2014.marasmus, https://www.google.com/url? sa $=$ t\&rct $=\mathrm{j} \& \mathrm{q}=\&$ esrc $=\mathrm{s} \&$ source $=$ web $\& \mathrm{~cd}=4 \& \mathrm{cad}=$ rja \&uact $=8 \&$ ved $=0 \mathrm{CDUQFj}$ AD\&url=http $\% 3 \mathrm{~A} \% 2 \mathrm{~F} \% 2 \mathrm{Fen}$. wikipedia.org\%2Fwiki \%2FMarasmus\&ei=7kJfVbfMJOj4ywPjvoH4Bw\&usg $=$ AFQjCNHvR6YVM1DehKsxK79k4DeoCkApbg\&b vm=bv.93990622,d.bGQ

[2] Taylor; (2012): Introduction to clinical nutrition. 3th ed. USA. Francis group. E-Book.

[3] http://emedicine.medscape.com/article/. Access on April 2015

[4] http://data.unicef.org/nutrition/malnutrition 2014 Accessed March 2015

[5] Carenlee.2012. Marasmus - Causes, Symptoms and Treatments, http://www.newsvine.com/ Access on April 2015

[6] American Academy of Pediatrics.2004. http://www.healthofchildren.com/P/Protein-EnergyMalnutrition.html Access on April 2015

[7] Ahmed, Eltayeb, Abdelmoniem, Amani; (2009): Management of Acute Severe Malnutrition, Sudan, FMOH 


\section{International Journal of Science and Research (IJSR) \\ ISSN (Online): 2319-7064 \\ Index Copernicus Value (2013): 6.14 | Impact Factor (2014): 5.611}

[8] Sudan Federal Ministry of Health; (2011): Inpatient Management of Severe Acute Malnutrition. https://www..fmoh.gov.sd. Accessed April .2015.

[9] http://www.fantaproject.org/sites/default/files/resource s/GOS_CMAM_IC Mod1_Introduction_Nov2011.pdf . Access on April 2015

[10] UNICEF.2014.malnutrition, statistics, Sudan. http://data.unicef.org /nutrition/malnutrition. 2014 Accessed March 2015.

[11] Sudan Federal Ministry of Health ;( 2013): Severe acute malnutrition. https://www..fmoh.gov.sd. Accessed April .2015.

[12] Puoane Thandi, Sanders, David, 2001, Evaluating the Clinical Management of Severely malnourished children http://archive.samj.org. Access on April 2015

[13] Raghavende, Suryavanshi.2008.. Apretorial Approach In The management of Marasmus in Children. E-book.

[14] (www.differencebetween.net Access on April 2015

[15] Murgod, Roopa , Ahmed MD Mustafa.2015.Nutritional Assessment In children with Protein Energy under nutrition instantue. International Journal of Applied Biology and Pharmaceutical Technology Volume-6, Issue-1,Page: 177.

[16] http://www.rightdiagnosis.com. Access on April 2015

[17] Nancy j. Peckenpan charlotte M, Poleman.1999. Nutrition Essentials and diet Therapy, 8thed.library of congress catalog in. USA.

[18] Mahan,L.,Kathleen, Sylvia,Escott-Stump.;(2008): Krause's,Food\& Nutrition Therapy, $12^{\text {th }}$ ed, Canada.

[19] Eleanor, schlenkerphd, \& Sara long2007, Essential of nutrition, and,diet,Therapy, $9^{\text {th }}$ ed., Websites,.www.elsev ier.com.\& www.bookaid.org.E.book.

[20] Mike, Ailsa, Brother ton, 2010.Malnutrition Matters Meeting Quality Standards in Nutritional Care, $1^{\text {st }}$ ed ,England, British Association for Parenteral and Enteral Nutrition. E-book.

[21] Republic of Uganda ministry of health, 2010, Integrated Management of Acute Malnutrition Guidelines. Uganda.

[22] Christopher, Duggan, john B., Watkins, Allan walker. 2009. Nutrition in Pediatrics $4^{\text {th }}$ ed peoples medical publisher house-USA.

[23] Hindi puoane ,David Sander, Ann Ashworth ,Mickey Chopra ,Susan strasser and David McCoy .International Society for Quality in Health Cares, International Journal for Quality in Health Care vol. 16 no. 1.2004;. London, UK

[24] Academy of Nutrition and Dietetics, 2015, Nutrition Care Processes.

[25] Academy of Nutrition and Dietetics.2015. Nutrition Care systems.

[26] http://www.nutritioncaresystems.com/nutrition-careprocesses

[27] Toulouse Purpan medical school.2009. Protein-Energy Malnutrition.

[28] Healthgrades.2015. http://www.rightdiagnosis.com.

[29] Medicalcare foundation .2014. www.medicalcare.com

[30] Worldfoodprogramme.2004.https://www.google.com/u $\underline{\mathrm{rl}}$ ? $\mathrm{sa}=\mathrm{t} \& \mathrm{rct}=\mathrm{i} \& \mathrm{q}=\&$ esrc $=\mathrm{s} \&$ source $=$ web $\& \mathrm{~cd}=1 \& \mathrm{cad}=\mathrm{r}$ ja\&uact $=8 \&$ ved $=0$ CB 4 QFjAA\&url $=$ https $\% 3 \mathrm{~A} \% 2 \mathrm{~F} \% 2$
Fwww.wfp.org\%2Fsites \%2Fdefault $\% 2$ Ffiles $\% 2$ FMicr onutrient $\% 2520$ Fortification $\% 2520 \mathrm{WFP} \% 2520$ Experi ences $\% 2520$ and $\% 2520$ Ways $\% 2520$ Forward $\% 2520 . \mathrm{pd}$ f\&ei=SiRgVai-

B8GZgwTGy4G4DA\&usg=AFQjCNHslvb0nyEyRgO LzL0J4CWBqV-U7Q\&bvm=bv.93990622,d.eXY

[31] Life science journals, and online books.2001. https://www.google.com/url? sa $=\mathrm{t} \& \mathrm{rct}=\mathrm{j} \& \mathrm{q}=\&$ esrc $=\mathrm{s} \&$ source $=$ web \&cd $=1 \&$ cad $=$ rja\&uact $=8 \&$ ved $=0 \mathrm{CB} 0 Q F j$ AA\&url=http $\% 3 \mathrm{~A} \% 2 \mathrm{~F} \% 2 \mathrm{Fwww} . n c b i . n l m . n i h . g o v \% 2$ Fpubmed\%2F11288395\&ei=oCZgVYieF4GvggT564 CoCw\&usg=AFQjCNH4nJ8Mv1ghPmqUquiAdwgTU 6W69Q\&bvm=bv.93990622,d.eXY

[32] Park, K. 2007. Textbook of Preventive and Social Medicine, 19th edition.

[33] Park, K. 2009. Textbook of Preventive and Social Medicine, 20th edition.

[34] WHO, 1998, Complementary feeding: family foods for breastfed children ,1998.

[35] WHO, 1999. Complementary feeding of young children in Africa and the Middle East. Geneva, 89-90.

[36] ePainAssist .2015. diatery treatment, http://www.epainassist.com.

\section{Author Profile}

Shadia Mohamed Idriss Bakheit received the B.Sc., M.Sc., PhD, and degree in Home Science / Nutrition from Ahfad University for women, university of Khartoum-Sudan, 1989, 1997, and 2000, respectively. She worked at Khartoum Teaching Hospital Sudan 1990-1997, University of Juba, College of Community Studies \& Rural Development 1997-2011, University of Bahri-Sudan 2011. University of Hail / KSA, 2011-2014. She worked now, as Associate professor at University of Bahri-Sudan.

Ali Adam Juma, B.Sc., University of Bahri-Sudan.

Bashir Awil Ismail, B.Sc., University of Bahri-Sudan. 
